\title{
Calcium Carbonate Scale Inhibition with Ultrasonication and a Commercial Antiscalant
}

\author{
Chanbasha Basheer ${ }^{1, *} \mathbb{D}^{\circ}$, Amjad A. Shaikh ${ }^{2}$, Eid M. Al-Mutairi ${ }^{2} \mathbb{D}$, Mokhtar Noor El Deen $^{1}(\mathbb{C}$ \\ and Khurram Karim Qureshi ${ }^{3}$ (D)
}

1 Department of Chemistry, King Fahd University of Petroleum and Minerals, Dhahran 31261, Saudi Arabia; mrashwan@ualberta.ca

2 Department of Chemical Engineering, King Fahd University of Petroleum and Minerals, Dhahran 31261, Saudi Arabia; ashaikh@hct.ac.ae (A.A.S.); emmutairi@gmail.com (E.M.A.-M.)

3 Department of Electrical Engineering, King Fahd University of Petroleum and Minerals, Dhahran 31261, Saudi Arabia; kqureshi@kfupm.edu.sa

* Correspondence: cbasheer@kfupm.edu.sa

Citation: Basheer, C.; Shaikh, A.A.; Al-Mutairi, E.M.; Noor El Deen, M.; Qureshi, K.K. Calcium Carbonate Scale Inhibition with Ultrasonication and a Commercial Antiscalant. Water 2021, 13, 3428. https://doi.org/ $10.3390 /$ w13233428

Academic Editor: Thomas M Missimer

Received: 4 November 2021 Accepted: 1 December 2021 Published: 3 December 2021

Publisher's Note: MDPI stays neutral with regard to jurisdictional claims in published maps and institutional affiliations.

Copyright: (c) 2021 by the authors. Licensee MDPI, Basel, Switzerland. This article is an open access article distributed under the terms and conditions of the Creative Commons Attribution (CC BY) license (https:// creativecommons.org/licenses/by/ $4.0 /)$.

\begin{abstract}
In this study, ultrasonication-assisted calcium carbonate scale inhibition was investigated compared with a commercial antiscalant ATMP (amino tris(methyl phosphonic acid)). The effects of varying ultrasound amplitude, $\mathrm{pH}$, and inhibition duration were evaluated. The inhibition of calcium carbonate scale formation was measured based on the concentration of calcium in the solution after subjecting to different conditions. Scale deposits were also characterized using scanning electron microscopy and X-ray diffraction spectroscopy. Inhibition of scale formation was supported at a $\mathrm{pH}$ of 7 for an ultrasound amplitude of $150 \mathrm{~W}$. A $94 \%$ calcium carbonate inhibition was recorded when the experiment was carried out with ultrasonication. The use of $5 \mathrm{mg} / \mathrm{L}$ ATMP achieved a $90 \%$ calcium carbonate inhibition of ATMP. The result of the characterization revealed that the morphology of the crystals was unaffected by ultrasonic irradiation. Sample treatment was performed with two different membranes to evaluate the calcium carbonate deposition, and data reveals that, at identical conditions, ultrasonication provides less deposition when compared to the control experiments.
\end{abstract}

Keywords: calcium inhibition; scale formation; reaction kinetics; porous membranes; ultrasound

\section{Introduction}

Scale formation occurs due to the precipitation of dissolved mineral salts. Mineral salt precipitation creates blockages in fluid channels, heat transfer surfaces, conveyance systems, condenser tubes, or membrane surfaces [1,2]. The growth of these precipitates often leads to heat transfer hindrance, energy consumption, equipment performance deterioration, shutdown, and productivity loss [3-5]. Scaling may occur in different industrial processes such as water transportation, oil and gas production, power generation, and batch precipitation [6,7]. There are various chemical treatment strategies to inhibit scale formation that involves prevention, reduction, or delay of inorganic scales.

Calcium carbonate is one of nature's most abundant minerals and significantly contributes to scaling formation [8]. Calcium carbonate can be an amorphous solid in three different crystalline forms: calcite, aragonite, and vaterite [9]. Aragonite is favored at high temperatures, while calcite is favored at low temperatures. The processes are triggering the decomposition of $\mathrm{HCO}_{3}{ }^{-}$according to the overall reaction:

$$
\mathrm{HCO}_{3}{ }^{-}(\mathrm{aq})=\mathrm{CO}_{3}{ }^{2-}(\mathrm{aq})+\mathrm{CO}_{2}(\mathrm{aq})+\mathrm{H}_{2} \mathrm{O}
$$

leading to the precipitation of $\mathrm{CaCO}_{3}$ once its solubility limit is reached.

$$
\mathrm{CO}_{3}^{2-}(\mathrm{aq})+\mathrm{Ca}^{2+}(\mathrm{aq})=\mathrm{CaCO}_{3}(\mathrm{~s})
$$


Calcium carbonate can be found in three different crystalline forms: calcite, aragonite, and vaterite. At high temperatures $\left(\mathrm{T}>70^{\circ} \mathrm{C}\right)$, aragonite is favored, while calcite is favored at low temperatures $\left(\mathrm{T}<30^{\circ} \mathrm{C}\right)$. Recent works have shown that less stable polymorphs such as vaterite and aragonite may be formed at room temperature due to wettability or flow instabilities. However, at any temperature, all polymorphs eventually recrystallize to the thermodynamically favored calcite $[10,11]$. The crystallization process occurs due to supersaturation, nucleation, and growth of crystals [12]. Supersaturation plays a crucial role in the crystallization process and prominently affects the nucleation rate [13]. The nucleation and crystal growth phenomenon conspicuously affect the crystal size distribution. To control the scale formation, a clear understanding of the crystallization process is of prime importance.

Several approaches have been adopted to control calcium carbonate scale formation [14,15]. Some of these include ion exchange softening [16], acid dosing [17], magnetic and electronic conditioners [18,19], surface modification [20] and ultrasound [21,22]. These methods control scale formation by altering the growth mechanisms of the crystals, changing the potential of a surface to foul, or affecting the solubility of the carbonates [23]. One of the most effective methods of inhibiting scale formation is by adding chemical inhibitors, also known as antiscalants [24]. Antiscalants derived from polyphosphates, organophosphates, and polyelectrolytes hinder scale formation by blocking growth sites. The mechanisms of antiscalants involve dispersion, crystal modification, and chelation. Crystal modification involves the distortion of the formed particle, resulting in an irregular, less adhesive crystal, preventing crystal growth at calcite surfaces $[25,26]$. The chemical scale inhibitors are continuously injected into the reservoir that controls the nucleation process of crystals and prevents the adhesion to the surface of pipes [27]. They are not environmentally friendly due to their chemical effect on treated water and the surrounding environment. Antiscalants are also expensive and require large quantities to treat water [28]. Hence, nowadays, there is an increasing need for new approaches that are environmentally friendly and economically feasible. Of these approaches, the application of ultrasound, magnetic, and electric fields has been reported [21].

The utilization of ultrasound for the calcium carbonate scale inhibition is a practical application due to the environment-friendly ultrasound. Ultrasonic irradiation successfully disintegrates and deactivates the clusters formed during the crystallization of $\mathrm{CaCO}_{3}$ [29]. The continuous use of ultrasonic waves in the liquid system produces bubbles. The bubble's collapse causes a cavitation effect, promoting the destruction of boundary layers, lowering supersaturation levels, and reducing clusters [30,31]. Dalas et al. reported that the application of ultrasound retarded the water-formed scale deposits by retarding the dehydration and diffusion steps of the calcium carbonate species formed in the solution [32]. Studies have also revealed that ultrasonic irradiation enhances the precipitation rate of calcium carbonate due to physical mixing [33]. In the quest to understand calcium carbonate precipitation rate, the effects of factors such as cavitation, ultrasonic intensity, and horn tip size have been studied [34]. The impact of ultrasound amplitude and frequency on the morphology of calcium carbonate precipitates has also been studied [35]. However, an in-depth understanding of other factors, such as conductivity, ultrasound amplitude, and chemical antiscalant during ultrasonic irradiation and $\mathrm{pH}$ is still essential. The primary purpose of this work is to investigate the effect of the $\mathrm{pH}$, ultrasound amplitude, and the addition of chemical antiscalant ATMP on calcium carbonate scale inhibition.

\section{Experiments}

\subsection{Reagents and Instruments}

Sigma Aldrich, Corporation of Germany, supplied calcium chloride $\left(\mathrm{CaCl}_{2} \cdot 6 \mathrm{H}_{2} \mathrm{O}\right)$, sodium chloride $(\mathrm{NaCl})$, sodium bicarbonate $\left(\mathrm{NaHCO}_{3}\right)$, and ethylenediaminetetraacetic acid (EDTA) of analytical grade. Commercial antiscalant ATMP (trade name: Hydrex 4102) with $\mathrm{pH}$ of 11.0-12.0, and the specific gravity of 1.35-1.45, was supplied by Veolia Water Technologies, Khoobar, Saudi Arabia. The flat sheet polypropylene and polysulfone 
membranes were purchased from Membrana (Germany). The surface morphology of the scales was obtained using a field emission scanning electron microscope (Lyra3 TESCAN FESEM). In contrast, the XRD diffractograms of the scales were obtained using a Rigaku Miniflex II desktop X-ray diffractometer with a $30 \mathrm{kV}$ tube output voltage.

\subsection{Saturated Calcium Carbonate Solution}

The calcium carbonate formation in actual field conditions takes a very long time. Thus, to accelerate the process, we prepared calcium carbonate at saturation conditions. The saturated calcium carbonate solution was prepared by mixing $86.0 \mathrm{mM}$ sodium chloride, $4.5 \mathrm{mM}$ calcium chloride, and $9.5 \mathrm{mM}$ sodium bicarbonate using deionized water (Millipore Q-Plus 185). The $\mathrm{pH}$ of the solutions was measured by a glass/saturated calomel electrode (Metrohm, Herisau, Switzerland), calibrated before and after each experiment. The $\mathrm{pH}$ of the working solution was adjusted by the addition of hydrochloric acid and ammonia buffer. Calcium carbonate precipitation initiated while adding calcium chloride and sodium bicarbonate

\subsection{Application of Ultrasonic Radiation and Study of Effect of Ultrasonic Amplitude}

Ultrasonic radiation was generated by an ultrasonic homogenizer working at a frequency of $20 \mathrm{kHz}$ and a rated power of $750 \mathrm{~W}$, with a horn immersed in the center of the reaction solution. The reaction solution of $0.500 \mathrm{dm}^{3}$ was placed inside a vessel of $13 \mathrm{~cm}$ in diameter and $14 \mathrm{~cm}$ height to achieve a solution surface height of $10 \mathrm{~cm}$. A volume of $10 \mathrm{~mL}$ of the working solution was taken every $15 \mathrm{~min}$ to determine the calcium ion concentration, filtered by a $0.25 \mu \mathrm{m}$ membrane, and then titrated with EDTA standardized solution.

The calcium carbonate scale deposition was carried out by weighing the polypropylene and polysulfone membranes. During the scale inhibition study, these membranes were placed inside the working solutions for 30 and $60 \mathrm{~min}$, respectively. Finally, they were dried in an oven for $1 \mathrm{~h}$ at $110^{\circ} \mathrm{C}$, and then the membranes were weighed, together with the deposits. At the end of the experiments, the solutions were filtered, and the precipitates were collected and examined by XRD to determine the crystal types of the deposited $\mathrm{CaCO}_{3}$ scales.

\section{Results and Discussions}

\subsection{Factors Affecting Scale Inhibition}

The $\mathrm{pH}$ of the sample solution played a crucial role when ultrasonic inhibition was applied. Figure 1 shows that calcium concentration steeply decreases when ultrasonication was performed in a relatively basic solution at the start of the experiment. However, there is a slight decrease in Ca concentration at $\mathrm{pH} 8.0$ and $\mathrm{pH} 7.0$ up to $30 \mathrm{~min}$. With the passing time, the amount of $\mathrm{Ca}$ continues to decrease, and at $\mathrm{pH} 9.0$, it changes from 4.5 to $4.2 \mathrm{mM}$, compared to $4.3 \mathrm{nM}$ at $\mathrm{pH} 8.0$ and $4.25 \mathrm{nM}$ at pH 7.0. These outcomes revealed more formation about the calcium carbonate scales in the solution with relatively higher alkalinity. However, the ultrasound scale inhibition shows better performance at neutral $\mathrm{pH}$. The effect of $\mathrm{pH}$ can be interpreted based on the $\mathrm{pH}$ dependence of carbonate concentration in the solution. Bicarbonate dissociates into carbonate according to the equation:

$$
\begin{gathered}
\mathrm{HCO}_{3}{ }^{-} \rightleftharpoons \mathrm{CO}_{3}{ }^{2-}+\mathrm{H}^{+}(\mathrm{pKa}=10.33) \\
\mathrm{pH}=\mathrm{pK}_{\mathrm{a}}+\log \left[\mathrm{CO}_{3}{ }^{2-}\right] /\left[\mathrm{HCO}_{3}{ }^{-}\right]
\end{gathered}
$$

According to the Henderson-Hasselbalch equation, as $\mathrm{pH}$ increases, the carbonate concentration increases, as indicated in Table 1: 
Table 1. Effect of $\mathrm{pH}$ on carbonate concentration at $9.5 \mathrm{mM}$ bicarbonate solution.

\begin{tabular}{cc}
\hline $\mathrm{pH}$ & {$\left[\mathrm{CO}_{3}{ }^{2-}\right] / \mathrm{mM}$} \\
\hline 7 & $4.44 \times 10^{-9}$ \\
8 & $4.44 \times 10^{-8}$ \\
9 & $4.44 \times 10^{-7}$ \\
\hline
\end{tabular}

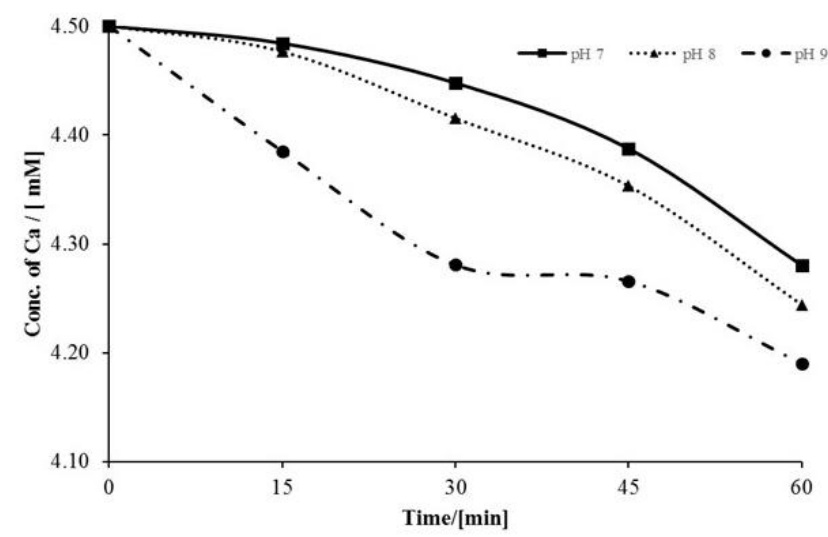

Figure 1. Effect of $\mathrm{pH}$ on calcium concentration over time during the ultrasonication process.

Increasing $\mathrm{pH}$ by two units increases the carbonate concentration by two orders of magnitude, increasing the chance of calcium and carbonate ions recombination, hence increasing the rate of calcium carbonate precipitation. These findings are supported by the fact that the dissolved carbon is distributed among three different species, $\mathrm{H}_{2} \mathrm{CO}_{3}, \mathrm{HCO}_{3}{ }^{-}$ and $\mathrm{CO}_{3}{ }^{2-}$, as a function of $\mathrm{pH}$ in a carbonate system. This distribution of carbonate species is derived from the Henderson-Hasselbalch relationship, knowing $\mathrm{pH}$ and $\mathrm{pK}$. At low $\mathrm{pH}, \mathrm{H}_{2} \mathrm{CO}_{3}$ is the dominant species. Starting from $\mathrm{pH} 5, \mathrm{HCO}_{3}{ }^{-}$will appear until being dominant from $\mathrm{pH} 6-10$. When increasing $\mathrm{pH}$ to $8, \mathrm{CO}_{3}{ }^{2-}$ will appear in the system, being the prevalent species at $\mathrm{pH} 9$ and above [36].

While the precipitation of the $\mathrm{CaCO}_{3}$ happens, it also alters the $\mathrm{pH}$ of the solution. This phenomenon is observed when the $\mathrm{pH}$ of the solution was monitored every $15 \mathrm{~min}$ to determine the extent of scale precipitation with time. Figure 2 illustrates the variation of $\mathrm{pH}$ for control and sonicated cases. The change in the solution $\mathrm{pH}$ was monitored with control and ultrasonicated samples. Results revealed that sample $\mathrm{pH}$ decreases up to $1 \mathrm{~h}$, and then no significant differences were observed. After $60 \mathrm{~min}$, complete precipitation was observed in control samples, whereas in the ultrasonicated sample, it further decreases to keep constant. As calcium carbonate precipitates, the protons are released according to:

$$
\mathrm{a}^{2+}{ }_{(\mathrm{aq})}+\mathrm{HCO}_{3}{ }^{-}{ }_{(\mathrm{aq})} \rightleftharpoons \mathrm{CaCO}_{3(\mathrm{~s})}+\mathrm{H}^{+}{ }_{(\mathrm{aq})}
$$

The $\mathrm{pH}$ of the control (untreated) sample displays a decrease from 9.0 to 8.2. In contrast, that of the sonicated sample $\mathrm{pH}$ decreased from 9.0 to 7.8 , indicating that less calcium carbonate precipitated in the case of sonicated water samples.

In order to investigate the effect of ultrasound waves on the precipitation reaction, different amplitudes of 150 and $450 \mathrm{~W}$ were applied to the sample and compared with the control experiment. Outcomes shown in Figure 3 revealed that at the start of the experiment, a more pronounced decrease in the concentration of calcium was observed under the influence of ultrasound irradiation as compared to the control experiment. Nevertheless, after $60 \mathrm{~min}$, it can be observed that calcium concentration in solution decreased from 4.5 to $3.1 \mathrm{mM}$ at $450 \mathrm{~W}$, while decreasing to $2.8 \mathrm{mM}$ in the case of the control experiment. Conversely, there is a negligible decrease in Ca concentration when $150 \mathrm{~W}$ ultrasonic radiations were employed. The presence of more calcium ion concentration in the solution means less precipitate formed when ultrasound irradiation is applied. This may be because irradiating the solution with ultrasound dissociates the water molecules 
so that they can be able to solvate the calcium and carbonate ions. Hence, they will not react with precipitation and dissolved calcium carbonate. At $150 \mathrm{~W}$, calcium concentration decreased to $4.2 \mathrm{mM}$, which is higher than $450 \mathrm{~W}$, which confirms better inhibition of the precipitation of the salt at $150 \mathrm{~W}$. This attributed to the fact that, at $150 \mathrm{~W}$, the effect of physical mixing of solutions is lower and results to a lower precipitation rate.

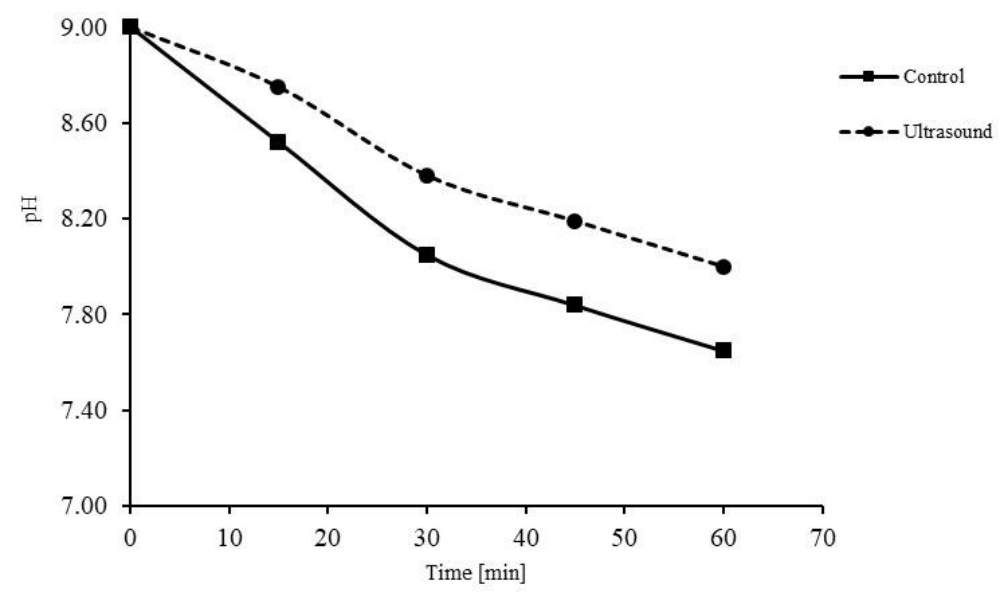

Figure 2. Comparison of $\mathrm{pH}$ variation with and without ultrasound treatment.

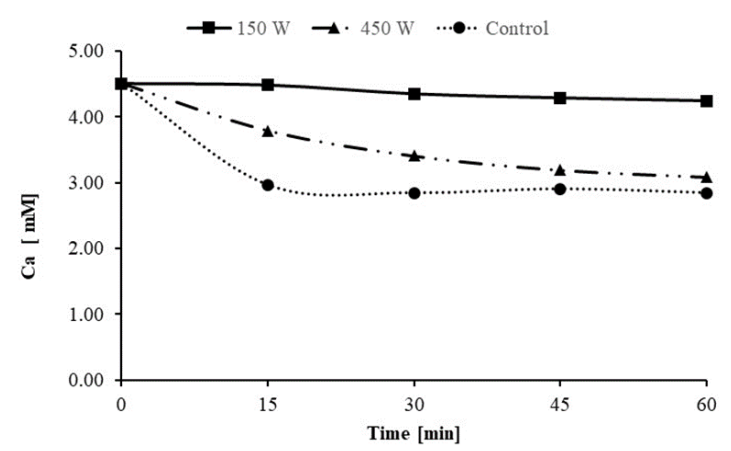

Figure 3. Effect of ultrasound amplitude on calcium concentration.

The effect of the addition of chemical antiscalants during ultrasound irradiation was studied by adding different dosages (from 0 to $10 \mathrm{mg} / \mathrm{L}$ ) of ATMP. The effect is expressed as calcium carbonate inhibition percentage $(\mathrm{CCI} \%)$ :

$$
\mathrm{CCI} \%=\frac{\left[\mathrm{Ca}^{2+}\right]_{\text {sample }}}{\left[\mathrm{Ca}^{2+}\right]_{\text {initial }}} \times 100 \%
$$

where $\left[\mathrm{Ca}^{2+}\right]_{\text {initial }}$ is the calcium ion concentration at $\mathrm{t}=0$ and $\left[\mathrm{Ca}^{2+}\right]_{\text {sample }}$ is the calcium concentration at time $(\mathrm{t})$. Figure 4 demonstrates the performance of ultrasonication on calcium ion inhibition over control and ATMP. Ultrasonication improved the inhibition considerably when compared to the control sample (without ultrasonication). CCI\% increased from $63.16 \%$ to $94.32 \%$ after $60 \mathrm{~min}$. However, the addition of ATMP during ultrasound irradiation had a negative effect on the scale inhibition behavior, as shown in Figure 4. The reason for the CCI\% drop might be due to the fission of the C-P bond of the antiscalant and the formation of calcium orthophosphate beside calcium carbonate. Hence, more calcium ions were consumed by the solution due to the precipitation of calcium orthophosphate. 


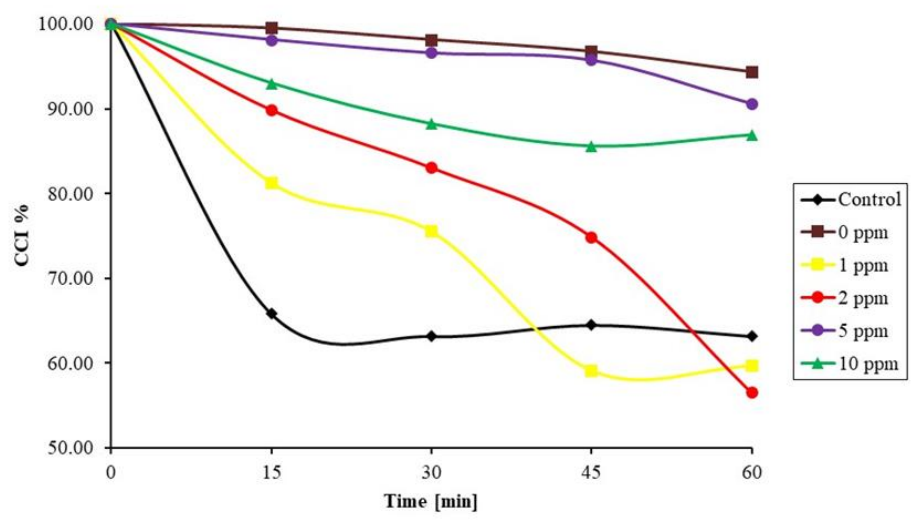

Figure 4. Effect of different dosages of amino tris(methyl phosphonic acid (ATMP) on ultrasonication with the control sample. At a lower dosage $(1 \mathrm{mg} / \mathrm{L})$, the treatment is not sufficient; 5 or $10 \mathrm{mg} / \mathrm{L}$ of ATMP is required to obtain comparable ultrasonication performance.

Conductivity variations were observed to demonstrate the effect of physical scale inhibition on the conductivity of the sample. Figure 5 shows the conductivity variation of untreated and sonicated water for $60 \mathrm{~min}$. The conductivity drop in the case of an untreated water sample is higher than that in the sonicated water sample. This contributed to the formation of more calcium carbonate precipitate in the untreated water, which leads to more calcium and bicarbonate ions consumption for the solution and hence lowers the electrical conductivity of the untreated water with time. On the other hand, the cavitation resulted in an increased number of ions in the aqueous samples. Consequently, sonicated samples show better conductivity.

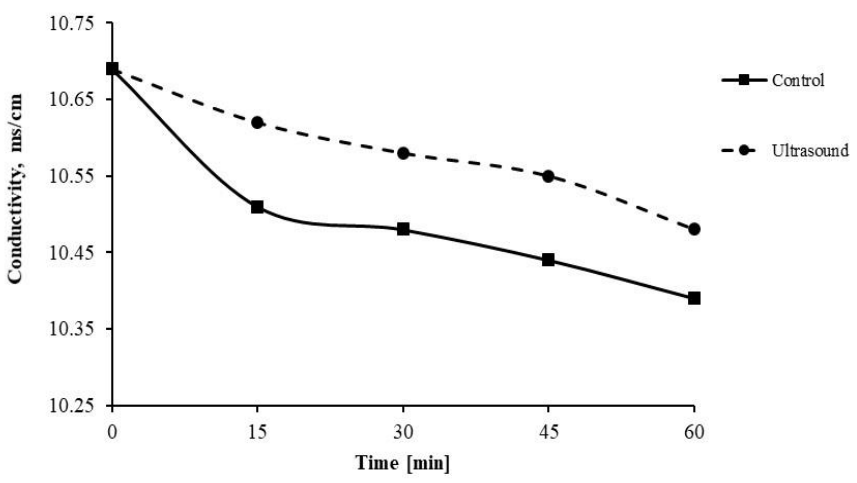

Figure 5. Comparison of conductivity variation with and without sonication.

\subsection{Characterization of Scale Deposits}

\subsubsection{Membrane Scale Deposit Measurements}

Calcium carbonate deposition on membrane-based water treatment industries suffers significant problems. To evaluate the amount of scales deposited, polypropylene (hydrophobic) and polysulfone (hydrophilic) membranes were utilized. Figure 6 shows the mass of calcium carbonate deposited on polypropylene and polysulfone membranes kept in the working solutions for 30 and $60 \mathrm{~min}$. The outcomes revealed that the amount of scale deposited in the case of the sonicated sample is insignificant compared to that of the control. The lower precipitation rate explains the lower scale deposition in the case of ultrasound application than the untreated sample. 


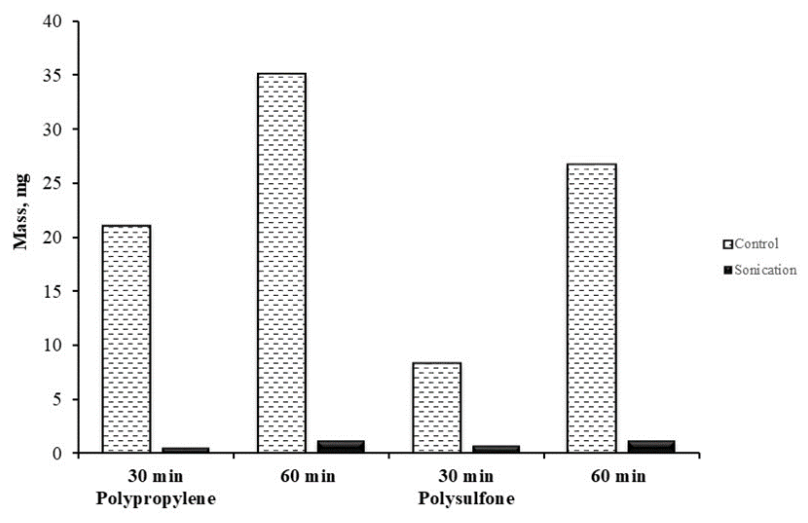

Figure 6. Weight measurements of calcium carbonate deposits with and without ultrasound application.

\subsubsection{SEM Micrograph and XRD Analysis}

SEM and XRD analyses were performed to confirm the nature of deposited $\mathrm{CaCO}_{3}$ crystals. The SEM micrographs of ultrasonicated and control samples were obtained to show the effect of ultrasound irradiation on the surface morphology of calcium carbonate deposits after precipitation. As shown in Figure 7, the crystals were obtained after ultrasonication, ATMP, and the control experiments after $60 \mathrm{~min}$. The ultrasonication strongly influenced the morphology of the crystals and the decomposition of the membranes. This can be seen from the SEM images that ATMP and ultrasonication produce soft crystals compared to the control experiments.
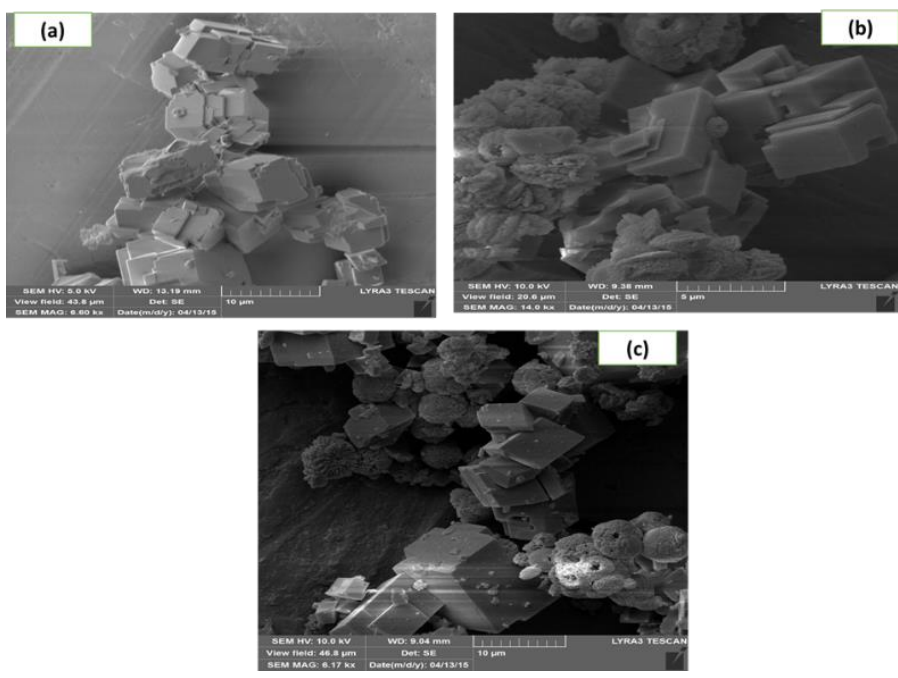

Figure 7. Scanning Electron Microscopy (SEM) images for deposits of (a) untreated control, (b) treated with ATMP, and (c) ultrasonicated sample after $60 \mathrm{~min}$.

Results are in agreement with the results obtained by Shivkumara et al. (2006) and Han et al. (2006) [37,38]. Additionally, from the surface morphology obtained, it can be inferred that crystals are made up of calcite and vaterite since it is widely accepted that calcite and aragonite have rhombohedric structures, while vaterite is spherical [28]. Additionally, minimal differences are observed in ATMP, and ultrasonicated samples indicate that the morphology of the crystals formed had a similar formation mechanism.

The XRD pattern of the crystals shown in Figure 8 also supports the SEM data. The comparison of the precipitated crystals is performed with the XRD spectra of standard peaks of calcite and vaterite, as shown in Figure 8b. The patterns show that the deposit mainly consists of calcite and vaterite, as depicted in the SEM data description. 


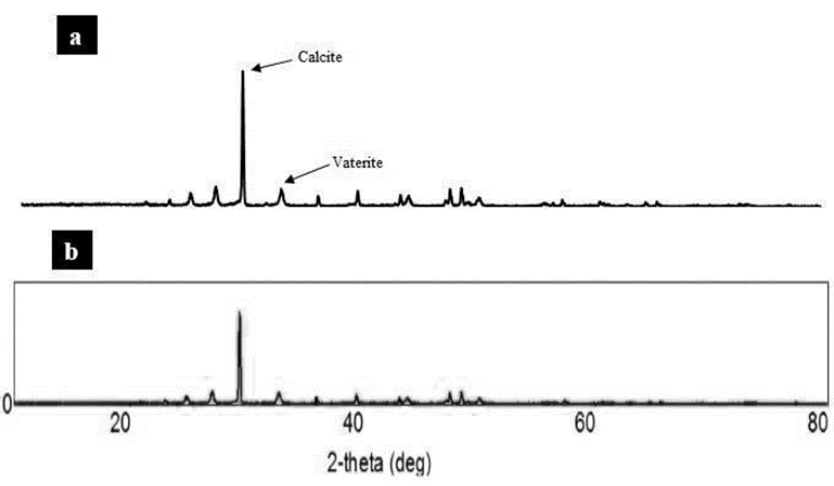

Figure 8. X-ray powder diffraction (XRD) spectra for (a) calcium carbonate crystals obtained from ultrasonication samples and (b) standard peaks of calcite and vaterite.

\subsection{Comparison of Ultrasound with Commercial Antiscalants}

The performance of ultrasonication and the ATMP method (without ultrasonication) for scale inhibition was also compared. Figure 9 shows photographs of the rate of calcium carbonate precipitation of untreated, chemically treated, and sonicated samples after $60 \mathrm{~min}$. Results demonstrate the suitability of the ultrasonication process with chemical treatment.

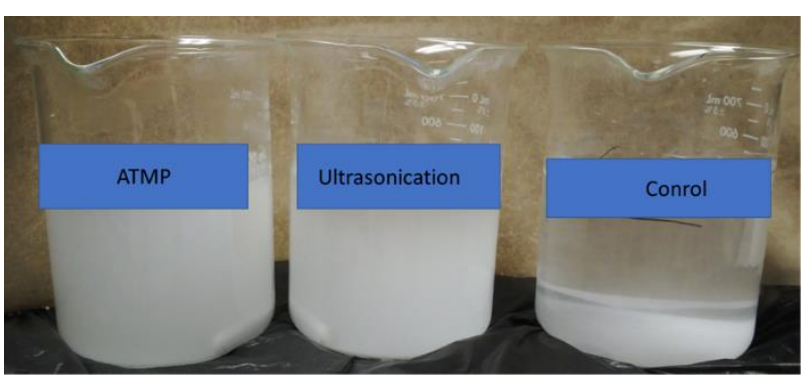

Figure 9. Photographs of ultrasonication treatment with ATMP and control after $60 \mathrm{~min}$.

A glance at Figure 10 reveals that the rate law of precipitation is parabolic, having a peak at $15 \mathrm{~min}$ - the induction period of calcium carbonate precipitation under these conditions-since calcium carbonate is a sparingly soluble salt. Additionally, also evident is the sharp decrease in the precipitation rate in the case of the treated samples. However, the sonicated water showed a sharper decline compared to the chemically treated one, due to the splitting of the solvent water molecules under the effect of ultrasound, solvating more calcium and carbonate species, preventing their recombination, and hence decreasing the rate of calcium carbonate precipitation.

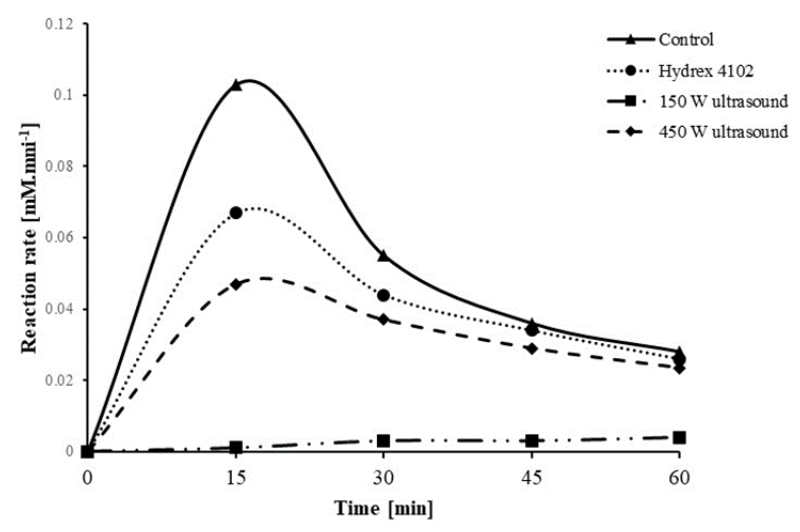

Figure 10. Comparative calcium carbonate precipitation rate of treated and untreated water samples. 


\section{Conclusions}

Calcium carbonate scale formation is a severe problem in many water treatment industries. Developing green technology is required to safeguard the environment. In this context, our study shows a promising result in laboratory conditions. Results suggest that the ATMP and ultrasonicated samples provide a significant decrease in scale formation and are stable even after $60 \mathrm{~min}$. The membrane deposition study indicates that ultrasonication strongly influenced the morphology of the crystals and provides less adhesion to the membranes. The application of ultrasound is a useful viable green approach compared to ATMP antiscalant treatment. Implementing this technology at the industrial setup will be the ultimate goal for this project. The ultrasound can be applied to retard the calcium carbonate fouling on the pipe surfaces in oil and gas plants. However, the optimized conditions obtained in the lab scale may not be suitable, and a customized approach is needed in the real-field environment. Research findings suggest that there is potential to develop non-chemical methods for industrial anti-scaling applications.

Author Contributions: Conceptualization, C.B., A.A.S.; methodology, M.N.E.D.; resources, C.B.; writing-original draft preparation, E.M.A.-M.; writing-review and editing, C.B. and K.K.Q.; visualization, K.K.Q. and E.M.A.-M.; supervision, C.B.; project administration, C.B.; funding acquisition, C.B. and A.A.S. All authors have read and agreed to the published version of the manuscript.

Funding: Funding support is from the King Abdul Aziz City for Science and Technology through the Science and Technology Unit at King Fahd University of Petroleum and Minerals for funding (project No. 10-WAT1399-04), as part of the National Science Technology and Innovation Plan.

Informed Consent Statement: Not applicable. No humans or animals were used.

Data Availability Statement: No additional data has been submitted.

Acknowledgments: The authors gratefully acknowledge the support of the King Abdul Aziz City for Science and Technology through the Science and Technology Unit at King Fahd University of Petroleum and Minerals for funding (project No. 10-WAT1399-04), as part of the National Science Technology and Innovation Plan.

Conflicts of Interest: The authors declare no conflict of interest.

\section{References}

1. Zarga, Y.; Boubaker, H.B.; Ghaffour, N.; Elfil, H. Study of calcium carbonate and sulfate co-precipitation. Chem. Eng. Sci. 2013, 96, 33-41. [CrossRef]

2. Younes, A.A.; El-Maghrabi, H.H.; Ali, H.R. Novel polyacrylamide-based solid scale inhibitor. J. Hazard. Mater. 2017, 334, 1-9. [CrossRef]

3. Antony, A.; Low, J.H.; Gray, S.; Childress, A.E.; Le-Clech, P.; Leslie, G. Scale formation and control in high-pressure membrane water treatment systems: A review. J. Memb. Sci. 2011, 383, 1-16. [CrossRef]

4. Chen, T.; Neville, A.; Yuan, M. Calcium carbonate scale formation-assessing the initial stages of precipitation and deposition. J. Pet. Sci. Eng. 2005, 46, 185-194. [CrossRef]

5. Yang, Y.; Kim, H.; Starikovskiy, A.; Fridman, A.; Cho, Y.I. Application of pulsed spark discharge for calcium carbonate precipitation in hard water. Water Res. 2010, 44, 3659-3668. [CrossRef]

6. Demadis, K.D.; Mavredaki, E.; Stathoulopoulou, A.; Neofotistou, E.; Mantzaridis, C. Industrial water systems: Problems, challenges, and solutions for the process industries. Desalination 2007, 213, 38-46. [CrossRef]

7. Shen, Z.; Shi, J.; Zhang, S.; Fan, J.; Li, J. Effect of optimized three-component antiscalant mixture on calcium carbonate scale deposition. Water Sci. Technol. 2017, 75, 255-262. [CrossRef]

8. Al Nasser, W.N.; Al-Salhi, F.H.; Hounslow, M.J.; Salman, A.D. Inline monitoring the effect of chemical inhibitor on the calcium carbonate precipitation and agglomeration. Chem. Eng. Res. Des. 2011, 89, 500-511. [CrossRef]

9. Siva, T.; Muralidharan, S.; Sathiyanarayanan, S.; Manikandan, E.; Jayachandran, M. Enhanced Polymer Induced Precipitation of Polymorphous in Calcium Carbonate: Calcite Aragonite Vaterite Phases. J. Inorg. Organomet. Polym. Mater. 2017, 27, 770-778. [CrossRef]

10. Al-Hamzah, A.A.; East, C.P.; Doherty, W.O.S.; Fellows, C.M. Inhibition of homogenous formation of calcium carbonate by poly (acrylic acid). The effect of molar mass and end-group functionality. Desalination 2014, 338, 93-105. [CrossRef]

11. de Leeuw, N.H.; Parker, S.C. Surface Structure and Morphology of Calcium Carbonate Polymorphs Calcite, Aragonite, and Vaterite: An Atomistic Approach. J. Phys. Chem. B. 1998, 102, 2914-2922. [CrossRef] 
12. Gerdts, C.J.; Tereshko, V.; Yadav, M.K.; Dementieva, I.; Collart, F.; Joachimiak, A.; Stevens, R.C.; Kuhn, P.; Kossiakoff, A.; Ismagilov, R.F. Time-Controlled Microfluidic Seeding in nL-Volume Droplets To Separate Nucleation and Growth Stages of Protein Crystallization. Angew. Chem. 2006, 118, 8336-8340. [CrossRef]

13. Lindfors, L.; Forssén, S.; Westergren, J.; Olsson, U. Nucleation and crystal growth in supersaturated solutions of a model drug. J. Colloid Interface Sci. 2008, 325, 404-413. [CrossRef]

14. Szcześ, A. Influence of SDS on particle size and adhesion of precipitating calcium carbonate. Colloids Surfaces A Physicochem. Eng. Asp. 2008, 320, 98-103. [CrossRef]

15. Wu, Z.; Davidson, J.H.; Francis, L.F. Effect of water chemistry on calcium carbonate deposition on metal and polymer surfaces. J. Colloid Interface Sci. 2010, 343, 176-187. [CrossRef]

16. Venkatesan, A.; Wankat, P.C. Simulation of ion exchange water softening pretreatment for reverse osmosis desalination of brackish water. Desalination 2011, 271, 122-131. [CrossRef]

17. Liu, D.; Dong, W.; Li, F.; Hui, F.; Lédion, J. Comparative performance of polyepoxysuccinic acid and polyaspartic acid on scaling inhibition by static and rapid controlled precipitation methods. Desalination 2012, 304, 1-10. [CrossRef]

18. Alabi, A.; Chiesa, M.; Garlisi, C.; Palmisano, G. Advances in anti-scale magnetic water treatment. Environ. Sci. Water Res. Technol. 2015, 1, 408-425. [CrossRef]

19. Ou, H.-H.; Hsieh, L.-H.C. A synergistic effect of sodium gluconate and 2-phosphonobutane-1,2,4-tricarboxylic acid on the inhibition of $\mathrm{CaCO}_{3}$ scaling formation. Powder Technol. 2016, 302, 160-167. [CrossRef]

20. Tran, H.V.; Tran, L.D.; Vu, H.D.; Thai, H. Facile surface modification of nanoprecipitated calcium carbonate by adsorption of sodium stearate in aqueous solution. Colloids Surfaces A Physicochem. Eng. Asp. 2010, 366, 95-103. [CrossRef]

21. Tijing, L.D.; Lee, D.-H.; Kim, D.-W.; Cho, Y.I.; Kim, C.S. Effect of high-frequency electric fields on calcium carbonate scaling. Desalination 2011, 279, 47-53. [CrossRef]

22. Lipus, L.C.; Ačko, B.; Hamler, A. Electromagnets for high-flow water processing. Chem. Eng. Process. Process Intensif. 2011, 50, 952-958. [CrossRef]

23. MacAdam, J.; Parsons, S.A. Calcium carbonate scale formation and control. Rev. Environ. Sci. Bio./Technol. 2004, 3, 159-169. [CrossRef]

24. Liu, G.; Xue, M.; Liu, Q.; Yang, H.; Yang, J.; Zhou, Y. Maleic anhydride-allylpolyethoxy carboxylate copolymer as an effective and environmentally benign inhibitor for calcium carbonate in industrial cooling systems. RSC Adv. 2017, 7, 24723-24729. [CrossRef]

25. Shen, Z.; Li, J.; Xu, K.; Ding, L.; Ren, H. The effect of synthesized hydrolyzed polymaleic anhydride (HPMA) on the crystal of calcium carbonate. Desalination 2012, 284, 238-244. [CrossRef]

26. Bai, S.; Naren, G.; Nakano, M.; Okaue, Y.; Yokoyama, T. Effect of polysilicic acid on the precipitation of calcium carbonate. Colloids Surfaces A Physicochem. Eng. Asp. 2014, 445, 54-58. [CrossRef]

27. Sousa, M.F.B.; Bertran, C.A. New methodology based on static light scattering measurements for evaluation of inhibitors for in bulk $\mathrm{CaCO}_{3}$ crystallization. J. Colloid Interface Sci. 2014, 420, 57-64. [CrossRef] [PubMed]

28. Palanisamy, K.; Raj, K.S.; Bhuvaneswari, S.; Subramanian, V.K. A novel phenomenon of effect of metal on calcium carbonate scale, morphology, polymorphism and its deposition. Mater. Res. Innov. 2017, 21, 294-303. [CrossRef]

29. Kim, S.; Wei, C.; Kiang, S. Crystallization Process Development of an Active Pharmaceutical Ingredient and Particle Engineering via the Use of Ultrasonics and Temperature Cycling. Org. Process Res. Dev. 2003, 7, 997-1001. [CrossRef]

30. Su, M.; Han, J.; Li, Y.; Chen, J.; Zhao, Y.; Chadwick, K. Ultrasonic Crystallization of Calcium Carbonate in the presence of Seawater Ions. Desalination 2015, 369, 85-90. [CrossRef]

31. Hu, A.; Zheng, J.; Qiu, T. Industrial experiments for the Application of ultrasound on scale control in the Chinese sugar industry. Ultrason. Sonochem. 2006, 13, 329-333. [CrossRef]

32. Dalas, E. The effect of ultrasonic field on calcium carbonate scale formation. J. Cryst. Growth 2001, 222, 287-292. [CrossRef]

33. Nishida, I. Precipitation of calcium carbonate by ultrasonic irradiation. Ultrason. Sonochem. 2004, 11, 423-428. [CrossRef]

34. Stoica-Guzun, A.; Stroescu, M.; Jinga, S.; Jipa, I.; Dobre, T.; Dobre, L. Ultrasound influence upon calcium carbonate precipitation on bacterial cellulose membranes. Ultrason. Sonochem. 2012, 19, 909-915. [CrossRef] [PubMed]

35. Kojima, Y.; Yamaguchi, K.; Nishimiya, N. Effect of amplitude and frequency of ultrasonic irradiation on morphological characteristics control of calcium carbonate. Ultrason. Sonochem. 2010, 17, 617-620. [CrossRef]

36. Revelle, R. Physico-Chemical Factors Affecting the Solubility of Calcium Carbonate in Sea Water. SEPM J. Sediment. Res. 1934, 4 , 103-110. [CrossRef]

37. Shivkumara, C.; Singh, P.; Gupta, A.; Hegde, M.S. Synthesis of vaterite $\mathrm{CaCO}_{3}$ by direct precipitation using glycine and l-alanine as directing agents. Mater. Res. Bull. 2006, 41, 1455-1460. [CrossRef]

38. Han, Y.S.; Hadiko, G.; Fuji, M.; Takahashi, M. Crystallization and transformation of vaterite at controlled pH. J. Cryst. Growth 2006, 289, 269-274. [CrossRef] 